International Research Journal of Engineering, IT \& Scientific Research (IRJEIS) Journal Homepage: http://ijcu.us/online/journal/index.php/irjeis

Vol. 2 Issue 7, July 2016, pp. 41 49

ISSN: 2454-2261 Impact Factor: 3.605

DOI: 10.6084/m9.figshare.3412627 | ORCID: 0000-0002-7710-0339| Thomson Reuters ID: C-6767-2016

\title{
Primary Agricultural Credit Societies in India
}

\begin{abstract}
A. Saravanadurai *
N. Manimehalai ${ }^{* *}$

Article history:

Received May $1^{\text {st }}, 2016$

Revised May15 ${ }^{\text {th }}, 2016$

Approved June $3^{\text {rd }}, 2016$

\section{Keywords:}

Co-Operatives; Working Capital;

Grass Root Level;

Agricultural Credit;

Outstanding.

Abstract

Agriculture is a backbone of Indian economy. As per the census, about 68.8 percent of population resides in rural area and depending directly or indirectly upon agriculture for their livelihood. The contribution of this sector to the gross domestic product (GDP) is however declining very rapidly and is presently about 14.5 percent (in 2010-11) and this sector is also showing deceleration in growth rates. Therefore, it is very important for this sector to achieve higher growth rates and also be an engine of growth, so that growth in other sectors and overall growth rate of the economy can be achieved. The primary agricultural credit co-operative societies are considered to be the pillars of the entire cooperative edifice. The PACSs continue to be the main source of agricultural credit to the farmers in rural areas.

Copyright ( 2016 International Journal of College and University. All rights reserved.

Article cited by | DOI |Orcid | OAI DOAJ | Thomson Reuters | Scopus |

\section{Author correspondence:}

First author,

A. Saravanadurai, professor of economics, Periyar University, Salem.

Email: ayyaduraisaravanadurai@gmail.com

\section{Introduction}

A Primary Agricultural Credit Society (PACS) is a basic unit and smallest co-operative credit institutions in India. It works on the grassroots level (gram panchayat and village level). Since 1954, the Co-operative credit societies are meeting increasingly the Requirements of farmers. More than 60 percent of the credit seeds of farmers are met By the Co-operative societies. At one time the money lendors provided more than 70 Percent of the farmer,s credit needs, they are now providing 35 percent. Therefore, Co-operative credit would become so significant that the village money-lendors will have no role to play in rural finance.

The rural Co-operatives have played a significant role in areas of credit, agricultural production, agricultural processing and marketing. The guiding Principles of co-operatives are voluntary and open membership, democratic control and equitable distribution of profit and utilisation of resources. As per 2011 census, about 68.8 percent of the population resides in rural areas, depending directly or indirectly upon agriculture for their livelihood. Agriculture is the mainstay of the Indian economy because of its high share in employment. The contribution of this sector to the gross domestic product (GDP) is however declining very rapidly and is presently about 14.5 percent (in 2010-11) and this sector is also showing deceleration in growth rates. Therefore, it is very important for this sector to achieve higher growth rates and also be an engine of growth, so that growth in other sectors and overall growth rate of the economy can be achieved.
\end{abstract}

*Reader in Economics, Department Of Economics, Periyar University, Salem.

${ }^{* *}$ Assistant Professor of Economics, LRG. Government College for Women, Tirupur $-4 \&$ part time ph.d scholar, Department of Economics, Periyar University, Salem. 
Agriculture is a backbone of Indian economy. As per the census, about 68.8 percent of population resides in rural area and depending directly or indirectly upon agriculture for their livelihood. The contribution of this sector to the gross domestic product (GDP) is however declining very rapidly and is presently about 14.5 percent (in 2010-11) and this sector is also showing deceleration in growth rates. Therefore, it is very important for this sector to achieve higher growth rates and also be an engine of growth, so that growth in other sectors and overall growth rate of the economy can be achieved. The primary agricultural credit cooperative societies are considered to be the pillars of the entire cooperative edifice. The PACSs continue to be the main source of agricultural credit to the farmers in rural areas.

The Primary Agricultural Cooperative Societies (PACS) are the bottom-tier of three- tier Cooperative credit structure operating in the country. These are Short Term Cooperative Credit Structure functioning at the grassroots (Gram Panchayat) level. These are Primary Societies owned by farmers, rural artisans etc. and intended to promote thrift and mutual help among the members; cater to their credit requirements and provide credit-linked services like input supply, storage and marketing of agricultural produce etc. These Cooperative Credit Institutions with their deep reach in the rural areas and accessibility to the small and marginal farmers and the other marginalized populations have been playing a vital role in dispensation of agricultural credit.

\section{Research Method}

\subsection{Functions}

[a] It provide credit to the farmers, distribute inputs like fertilizers and also run outlets under Public Distribution System.

[b] These banks provide short term and medium term credit for agriculture and allied activities.

[c] The short term loans are repayable within a period of 12 to 15 months and the medium term loans are repayable within 3 to 5 years.

[d] Crop loan is the prominent item of credit to the farmers by Primary Agricultural Cooperative Credit Societies, provided without collateral security upto 10 acres in respect of registered sugarcane growers and upto Rs. 1 lakh in respect of other crops.

[e] The loan amount exceeding this limit is secured with mortgage of property or pledge of jewels.

[f] Primary Agricultural Cooperative Credit Societies also issue loans for other agricultural purposes like purchase of farm machineries and for non-agricultural purposes including loans for the purchase of consumer durables, housing loans, education loans and professional loans.

[g] To provide marketing facilities for the sale of agricultural produce

[h] To associate itself with economic and social welfare programmes of the village.

Considering the importance of increasing credit flow into the agriculture sector, Government has reduced the interest rate for the crop loans from $9 \%$ to $7 \%$ per annum from 2006-07, the interest differential being compensated by the Government. The Government is taking all efforts to inculcate the habit of financial discipline among the farmers. As a special measure, Government have announced further reduction of interest from $7 \%$ to $5 \%$ for all crop loans being repaid promptly by the farmers. This has been further reduced to $4 \%$ in $2008-09$.

The Government lays emphasis on the timely disbursement of crop loan in adequate quantity. It is proposed to disburse Rs.1500 crores as crop loan during 2008-09. It is further proposed that the lending through Farmers Group will be encouraged by forming Joint Liability Groups which will benefit the farmers to get additional assistance by way of revolving fund to the tune of Rs. 10 crores. This is expected to benefit the farmers in a great way to consolidate themselves and pool their resources in arranging their inputs supply, organizing cultivation activities and making joint efforts in marketing to fetch a better price for their produce. Ultimately this will pave way for consolidation of the farming activities by the farmers facilitating appropriate technological intervention for improving the productivity of the farm sector.

As a policy, this Government is not for liquidation of any Primary Agricultural Cooperative Societies which has been set up for the specific purpose of serving the farmers in their respective operational areas.

This Government considers that Primary Agricultural Cooperative Credit Societies are the fulcrum on which integrated package of services such as credit, insurance, inputs; marketing and extension can be delivered to the farmers. Recognising the importance of increasing productivity in agricultural sector as envisaged in the XI Five Year Plan, Primary Agricultural Cooperative Credit Societies will be actively engaged in provision of integrated service to the farmers and serve as a point of dissemination of the technology and the improved cultivation practices. It is expected to increase the prosperity of farmers by availing better services particularly in the area of technological intervention. In this process, Primary Agricultural Cooperative Credit Societies will actively collaborate with Agriculture Department and the Research \& Development organisations and provide all inputs and services under one roof.

The Primary Agricultural Cooperative Credit Societies will also act as Paddy Procurement Centres on behalf of Tamil Nadu Civil Supplies Corporation and will procure paddy at the minimum support price 
announced by the Government in the non-delta areas apart from Direct Purchase Centres operated by Tamil Nadu Civil Supplies Corporation. Primary Agricultural Cooperative Credit Societies will also assist the Cooperative Marketing Societies, Tamil Nadu Cooperative Marketing Federation and National Agricultural Cooperative Marketing Federation of India (NAFED) to procure the agricultural produce directly from the farmers.Primary Agricultural Cooperative Credit Societies will expand their produce pledge loan operations substantially to prevent distress sale by the farmers during peak harvest.

\subsection{Objectives of Primary Agricultural Cooperative Societies (PACS)}

[a] To cater to the credit need, mostly, farm credit and income generation activities of farmers, artisans and other members.

[b] To extend selected banking services to members.

[c] To implement Kissan Credit Card Scheme for providing timely and adequate farm credit to members.

[d] To take up marketing of agricultural produce of member farmers.

[e] To cater to the consumer needs, mostly, essential commodities of members.

[f] To create awareness among farmers to adopt improved farming practices.

[g] To reach upto the unprivileged section of the community through SHGs, JLGs and TFGs.

[h] For the membership of Co-operative credit societies member should be belong to located village of Co-operative societies.

[i] The work of co-operative societies should limited to its village only.

[j] The liability of Co-operative credit societies be should unlimited.

[k] Co-operative credit society is liable for to the deposits and loans in its account.

[1] Co-operative credit society should be providing loans to its member only.

[m] Loan repayment schedule can be deciding by the co-operative society as per the significance purpose of the loans.

[n] Primary Co-operative credit societies provide the loan only for medium and short term purpose.

\subsection{Current Status of Primary Agricultural Cooperative Societies (PACS)}

PACS are important structures that have been provding credit facilities mainly to the farmers in vallges of India. It has the deepest penetration amongst all the other credit providing institutions. Currently, India has 93,000 PACS - one for every seven villages. In contrast, commercial and Regional Rural Bank (RRBs) have just 50,000 branches across rural and semi-urban India. During 2011-12, PACS lent to 3.09 crore farmers. The comparable numbers for commercial banks and RRBs are 2.55 crore and 82 lakh. During 201112, for instance, PACS financed 67 lakh new farmers compared to 21 lakh for commercial banks and 9 lakh by RRBs. Further, PACS have a reputation for lending to small and marginal farmers - as co-operatives, they are owned and run by farmers.

\subsection{Objective of the study}

[a] To know about the Total Number of primary agriculture Co-operative societies during the period of 2000-01 to 2009-10.

[b] To study the Total Members, SC Members and ST Members of primary agricultural cooperative credit societies

[c] To study the Deposits, Borrowings and Working Capital in Primary Agriculture Society.

[d] To explain the Information regarding the loan issued and loan outstanding of primary agricultural credit societies.

[e] To know about the Total collection of Loans and Overdues of primary agricultural credit societies during 2000-01 to 2009-10.

\section{Results and Analysis}

Table 1. Number of primary agriculture Co-operative societies during the period of 2000-01 to 2009-10.

\begin{tabular}{|l|l|l|}
\hline Year & Numbers & Percentage \\
\hline $2000-01$ & 98843 & 8.87 \\
\hline $2001-02$ & 98247 & 8.82 \\
\hline $2002-03$ & 112309 & 10.08 \\
\hline $2003-04$ & 105735 & 9.49 \\
\hline $2004-05$ & 108779 & 9.76 \\
\hline $2005-06$ & 106384 & 9.55 \\
\hline $2006-07$ & 97224 & 8.73 \\
\hline $2007-08$ & 94950 & 8.52 \\
\hline $2008-09$ & 95633 & 8.58 \\
\hline $2009-10$ & 94647 & 8.49 \\
\hline
\end{tabular}




\begin{tabular}{|l|l|l|}
\hline Total & 1012751 & 100.00 \\
\hline
\end{tabular}

The Above Table shows the details of the number of Primary Agricultural Co-Operative Credit Societies during the Period 2000-01 to 2009-10. Total number of Paccs n these Period Was 1012751. The Number has been increasing gradually.

Number of primary agriculture Co-operative societies during the period of 2000-01 to 2009-10.

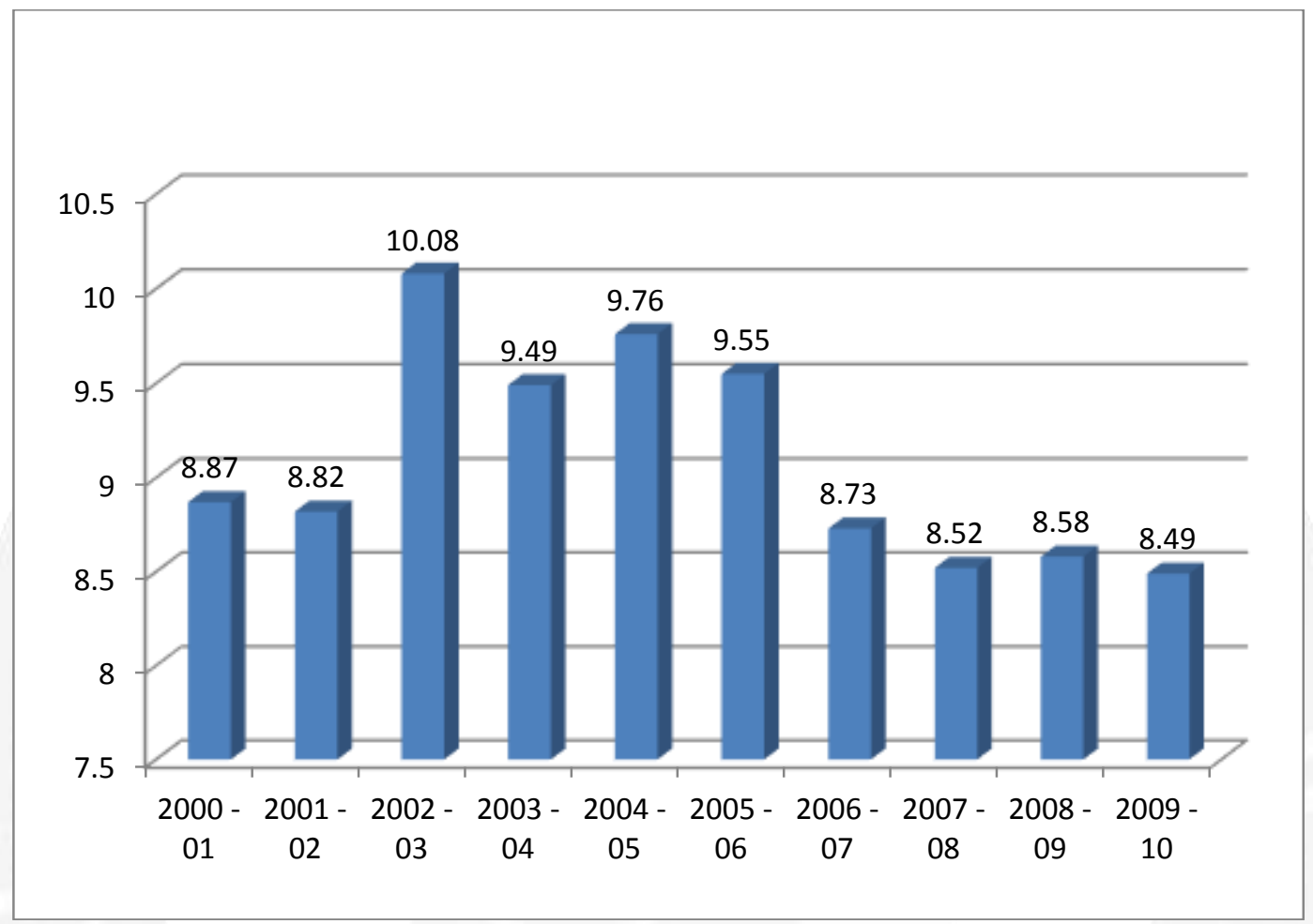

\subsection{Co-operative Credit Structure:}

The Co-operative institutions play a very important role in providing credit at the correct time at an affordable rate of interest.

The Co-operative Credit Structure in Tamil Nadu Comprises of the following.

[a] Short term and medium term credit structure

[b] Long term credit structure

[c] Urban Co-operative Banks'

The Short-term credit structure operates in three tires.

[a] Tamil Nadu State Apex Co-operative Bank (at the state level)

[b] Central Co-operative Banks(at the district level)

[c] Primary Agricultural Co-operative Banks(at the village level)

Primary Agriculture Co-operative Banks are functioning in the State, which provides short term loans to the farmers for cultivation purposes repayable Within 15 months. The number of PACS had come down from 98843 in 2000-2001 to in 1970-71 and 94647 in June 2009-2010.

The primary agricultural credit societies have stepped up their advances to the weaker sections particularly the small and marginal farmers. This progress has been quite spectacular but not adequate considering the demand for finance from farmers.

\subsection{Schemes of Co-operative Credit Structure:}

Various schemes are implemented by the Co-operative Credit Societies.

They are as follows:

[1] Waiver of Co-operative loans availed by farmers.

[2] Kisan credit card scheme.

[3] Micro Credit to women for small farmers.

[4] Assistance to self help groups.

[5] Working women loan scheme. 
[6] Maternity loan Scheme etc.,

Rather than the above said Schemes, the Co-operative Banks are extending the loans. During 2006-2007, a sum of Rs.20.00 lakhs has been provided at the rate of Rs.250/-per member as interest free share capital loan to 8000 scheduled caste and scheduled tribe members of the PACBS.District Central Co-operative banks are extending professional loans to doctors and engineers up to Rs.100 Lakhs at an interest rate of $12 \%$ per annum.During the year 2006-2007 a sum of Rs.44 lakhs has been disbursed to 2,207 women beneficiaries under Maternity loan scheme.

Table 2. Information Regarding the Total Members, SC Members, and ST Members.

\begin{tabular}{|l|l|l|l|}
\hline Years & $\begin{array}{l}\text { Total } \\
\text { Member }\end{array}$ & SC Members & ST Members \\
\hline 200001 & 8.13 & 5.11 & 7.79 \\
\hline 200102 & 8.31 & 5.15 & 9.24 \\
\hline 200203 & 10.05 & 12.47 & 11.04 \\
\hline 200304 & 11.01 & 11.50 & 10.92 \\
\hline 200405 & 10.36 & 11.62 & 10.84 \\
\hline 200506 & 10.18 & 11.49 & 10.71 \\
\hline 200607 & 10.23 & 10.99 & 10.22 \\
\hline 200708 & 10.70 & 11.17 & 10.29 \\
\hline 200809 & 10.76 & 10.70 & 9.30 \\
\hline 200910 & 10.28 & 9.80 & 9.66 \\
\hline Total & 100.00 & 100.00 & 100.00 \\
\hline
\end{tabular}

Source: Source: National Federation of State Co-operative bank ltd. (NAFSCOB)

Above table is displaying the performance in terms of category wise membership of members in primary agriculture co-operative societies. Total number of members has increased from 8.13 to 10.28 respectively in 2000-01 to 2009-10. Followed by that SC and ST categories member also increased from 5.11 to 9.80 and 7.79 to 9.66 respectively in 2000-01 to 2009-10 years. Maximum number of member has increased in 200304 with percentage of 11.01.In SC and ST category in 2002-03 the significant growth found with percentage of 12.47 and 11.04 respectively

Total Members, SC Members and ST Members.

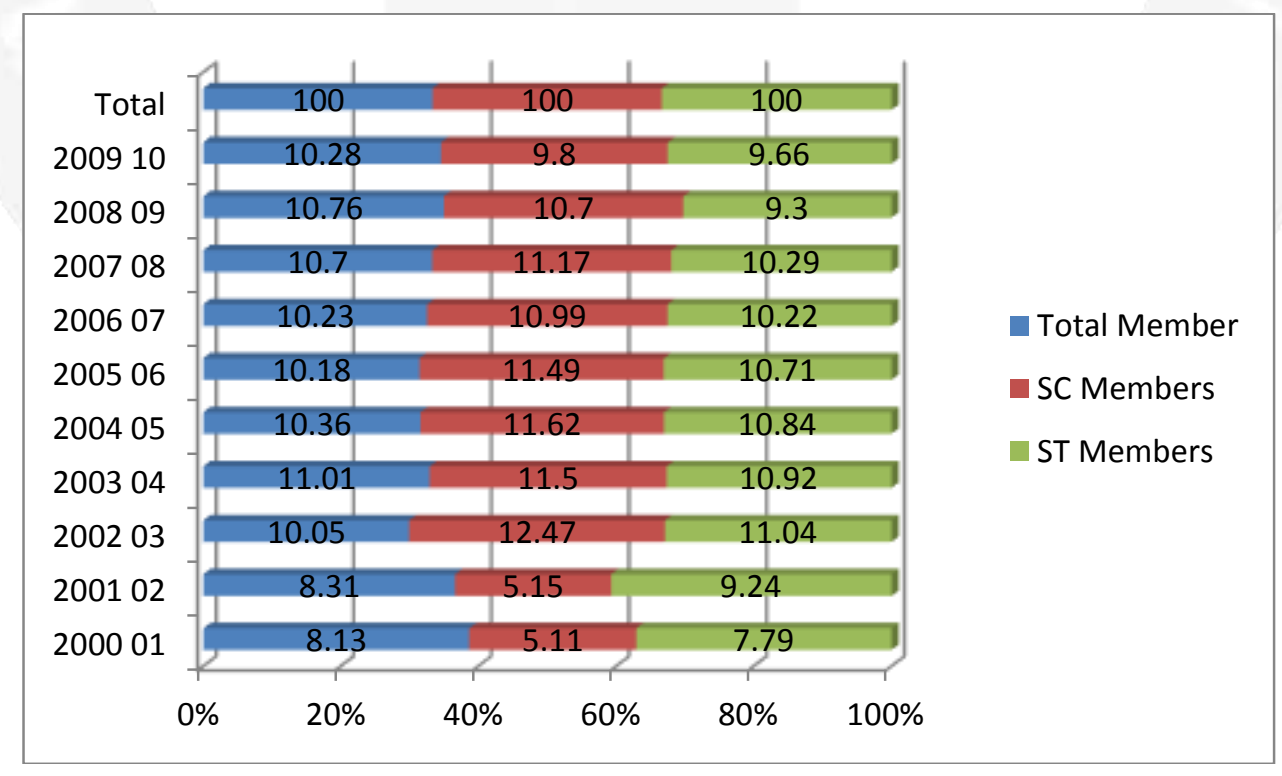

Table 3. Information regarding the Deposits, Borrowings, and Working Capital in Primary Agriculture Society. 


\begin{tabular}{|l|l|l|l|}
\hline Year & Total Deposits & $\begin{array}{l}\text { Total } \\
\text { Borrowings }\end{array}$ & $\begin{array}{l}\text { Working } \\
\text { Capital }\end{array}$ \\
\hline 200001 & 6.28 & 6.14 & 6.95 \\
\hline 200102 & 6.92 & 7.11 & 6.69 \\
\hline 200203 & 8.91 & 8.10 & 7.88 \\
\hline 200304 & 8.45 & 8.32 & 8.00 \\
\hline 200405 & 8.84 & 9.41 & 9.72 \\
\hline 200506 & 9.12 & 11.06 & 9.46 \\
\hline 200607 & 10.94 & 11.27 & 10.31 \\
\hline 200708 & 11.86 & 12.01 & 11.36 \\
\hline 200809 & 12.23 & 13.15 & 12.20 \\
\hline 200910 & 16.44 & 13.44 & 17.43 \\
\hline Total & 100.00 & 100.00 & 100.00 \\
\hline
\end{tabular}

Source: Source: National Federation of State Co-operative bank ltd. (NAFSCOB)

Table III Covering the information regarding the deposits, borrowings, and working capital of the primary agriculture co-operative societies in India. During the ten year of 2000-01 to 2009-10 total deposits has increased from the 6.28 percent to 16.44 percent. Similarly, total borrowings also increased from 6.14 percent to 13.44 percent. About the working capital there was significant progress found in respective era of 2000-01 to $2009-10$ with percent growth from 6.95 to 17.43 .

Deposits, Borrowings and Working Capital in Primary Agriculture Society.

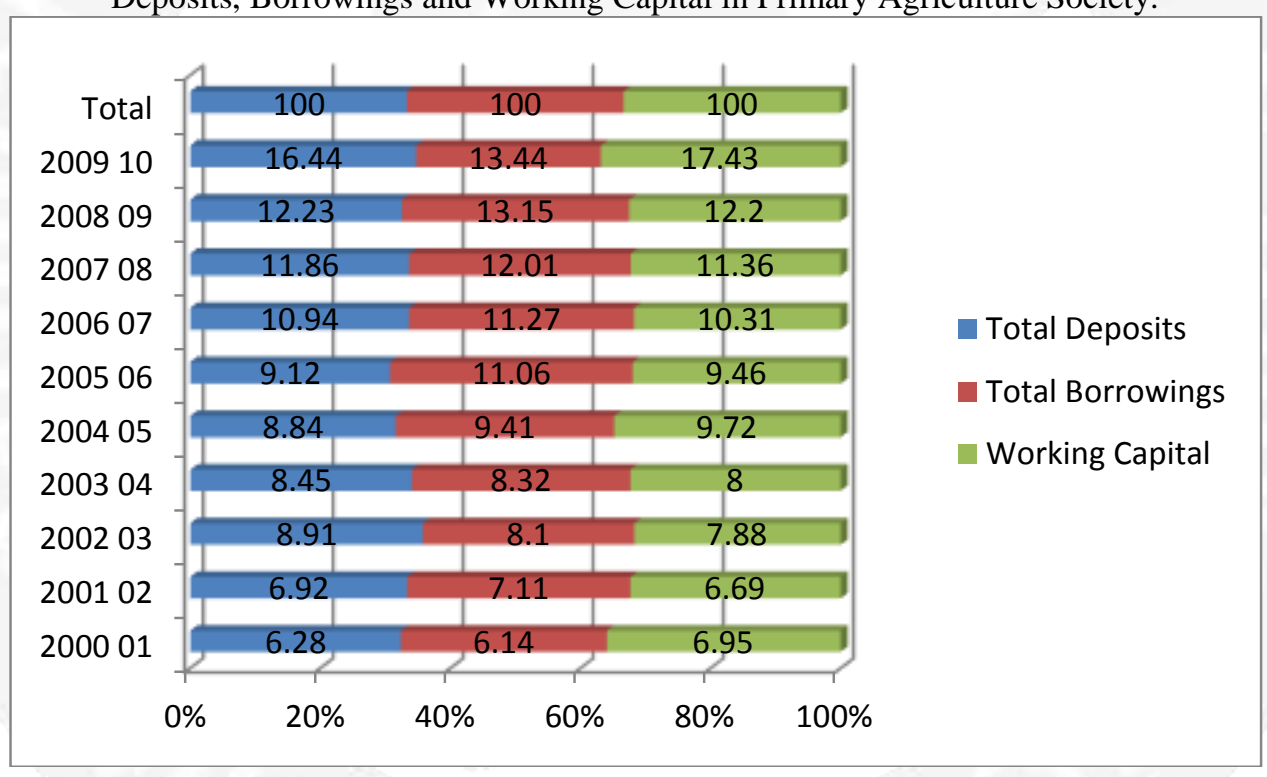

Table 4. Information regarding to the loan issued and loan outstanding

\begin{tabular}{|l|l|l|}
\hline Years & Loans Issued & $\begin{array}{l}\text { Loans } \\
\text { Outstanding }\end{array}$ \\
\hline 200001 & 5.73 & 6.55 \\
\hline 200102 & 6.86 & 7.74 \\
\hline 200203 & 7.58 & 8.05 \\
\hline 200304 & 7.83 & 8.33 \\
\hline 200405 & 8.74 & 9.26 \\
\hline 200506 & 9.57 & 9.83 \\
\hline 200607 & 11.06 & 11.12 \\
\hline 200708 & 12.85 & 12.46 \\
\hline 200809 & 13.10 & 12.15 \\
\hline 200910 & 16.70 & 14.51 \\
\hline Total & 100.00 & 100.00 \\
\hline
\end{tabular}

Source: Source: National Federation of State Co-operative bank ltd. (NAFSCOB) 
Table no. IV is indicating the figures in percent share of loan issued and loans outstanding as per the years. Amount of loans issued from the primary agriculture societies to farmer grown from 5.73 percent to 16.70 percent during 2000-01 to 2009-10 respectively. Similarly, in respective years, the amount of loans outstanding also increased from 9.55 to 14.51 percent.

\subsection{Details of loan issued and loan outstanding}

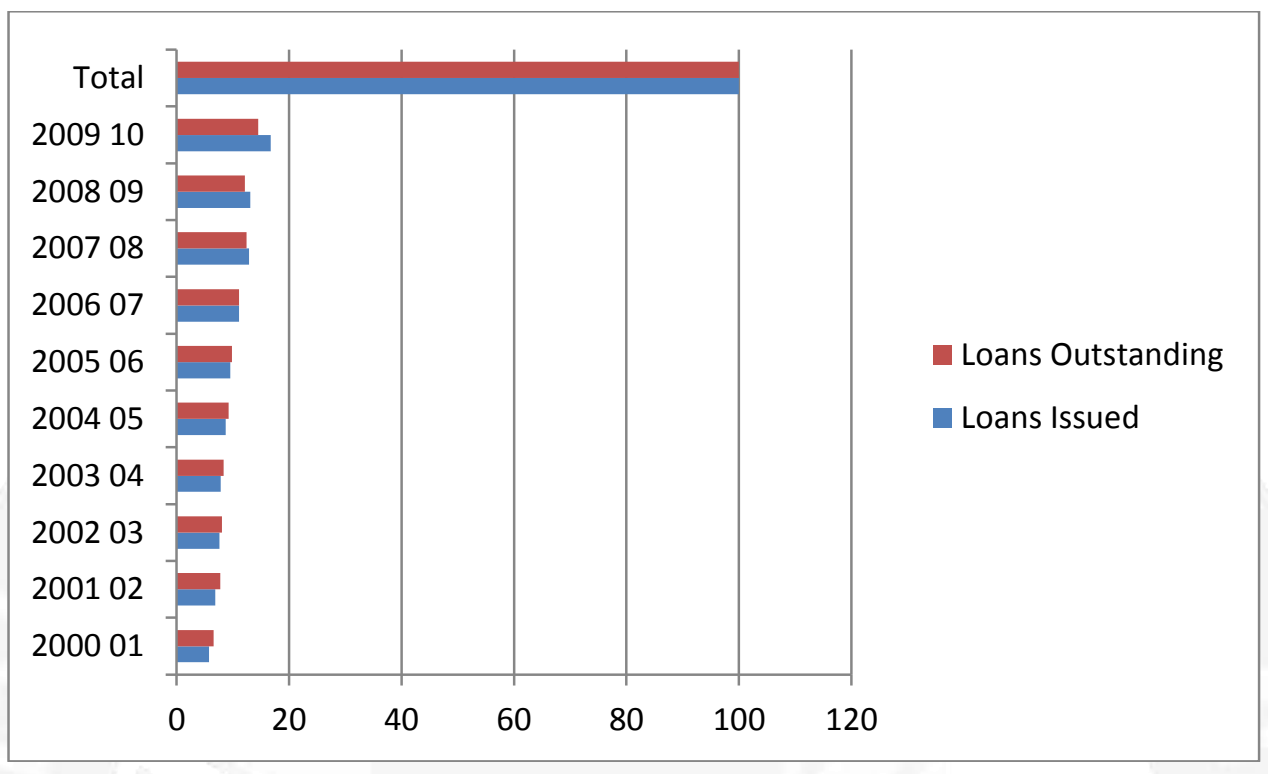

Table 5. Information regarding the Total collection of Loans and Overdue during 2000-01 to 2009-10

\begin{tabular}{|l|l|l|}
\hline Years & $\begin{array}{l}\text { Total } \\
\text { Collection }\end{array}$ & Total Overdue \\
\hline 200001 & 5.41 & 4.98 \\
\hline 200102 & 6.64 & 5.49 \\
\hline 200203 & 7.23 & 7.59 \\
\hline 200304 & 8.07 & 8.09 \\
\hline 200405 & 9.16 & 7.97 \\
\hline 200506 & 10.25 & 7.68 \\
\hline 200607 & 11.08 & 7.82 \\
\hline 200708 & 12.50 & 11.92 \\
\hline 200809 & 13.49 & 18.83 \\
\hline 200910 & 16.16 & 19.62 \\
\hline
\end{tabular}

Source: Source: National Federation of State Co-operative bank ltd. (NAFSCOB)

Table No. V is displaying the year wise percent share of total collection and total overdue. Total collection was 5.41 percent in 2000-01, which increased until to 16.16 percent in 2009-10. Total collection was greater than the total overdue in 2000-01 with percentage of 5.41 and 4.98 respectively. However, in 2009-10 position has changed, the total collection found lesser than the total overdue with percent of 16.16 and 19.62 respectively.

Total collection of loans and overdue during 2000-01 to 2009-10 


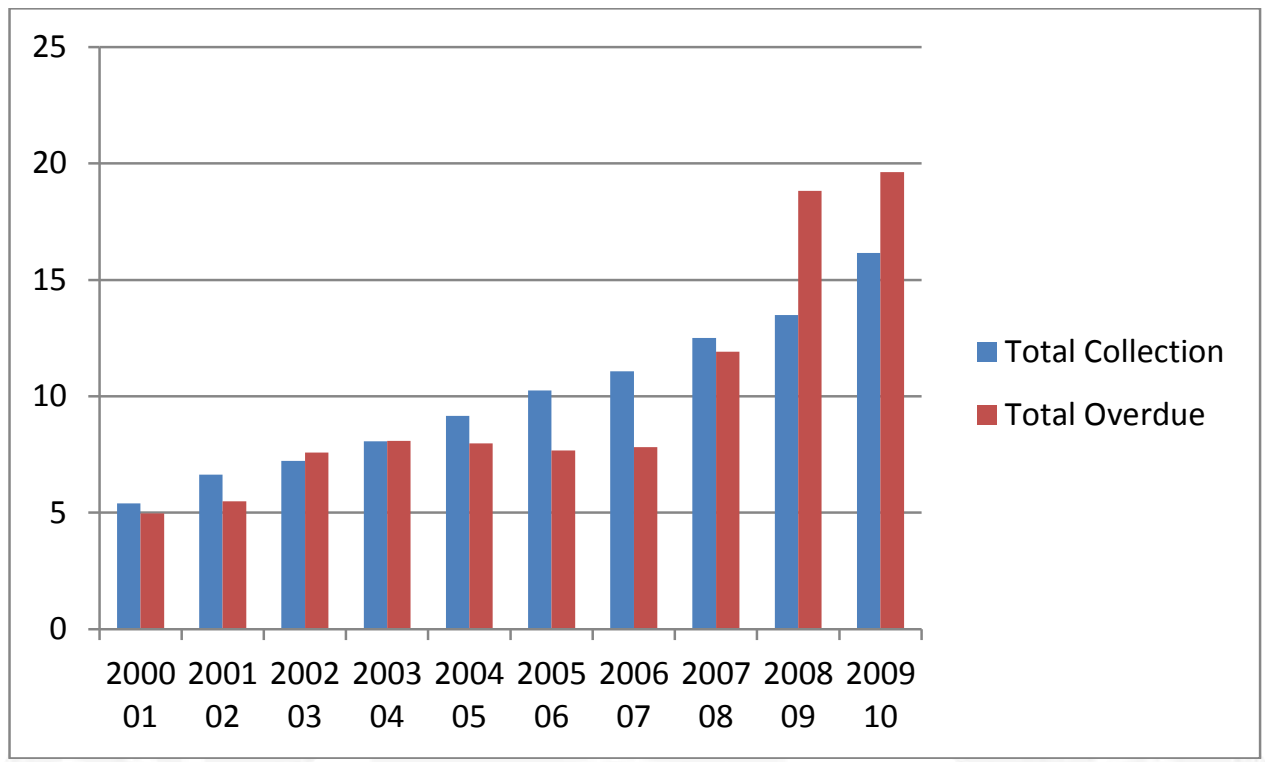

\section{Conclusion}

[a] Agriculture Co-operative Credit societies are working positively. However, there is negative direction found in the establishments in number of societies but the total numbers of members are increased during the ten years of 2000-01 to 2009-10. There is significant thing found that the SC membership are rapidly increased in that decade.

[b] Increasing number of members in Primary Agriculture Co-operative credit societies are indicating, that the farmer are getting awareness about the societies motivate and its benefits and so the farmer are like to take a membership in those societies. Therefore, the total numbers of members are increased by 8.13 percent to 10.28 percent during 2001-02 to 2009-10 respectively. However, it is not significant growth but it is showing farmers positive attitude about the PACs.

[c] Total borrowing, total deposits and working capital also increased. It is indicating the positiveness of primary agriculture societies in view of farmer's response. Farmer are depositing there money in society and they have a belief in the process of primary agriculture co-operative societies

[d] About the loans issued and outstanding the gap between both accounts are decreasing. That means farmer are repaying the loans to the primary credit co-operative society and these loans are not considering as a non-performing assets in a large frequency.

[e] Overall the performance of primary agriculture co-operative societies has shown not much better but good performance in the scene of progress and development.

\section{References}

[1] Co-Operative Information Guide

[2] E.V: Velu, Minister for Food and Co-Operation

[3] Indian Economy, Ruddar Datt, K.P.M. Sundharam, Tamil Nadu Journal of Co-Operation

[4] Laha and Kuri (2011): Indian Journal of Agriculture Economics, Jan.1.2011.

[5] Policy Note 2007-2008 Co-Operation (Co-Operation Food and Consumer Protection Department)

[6] S.S.Kalamkar: The Maharashtra Co-operative Quarterly Vol. 89, No.

[7] Sankaran: Indian Economy and Development 


\section{Authors biography}

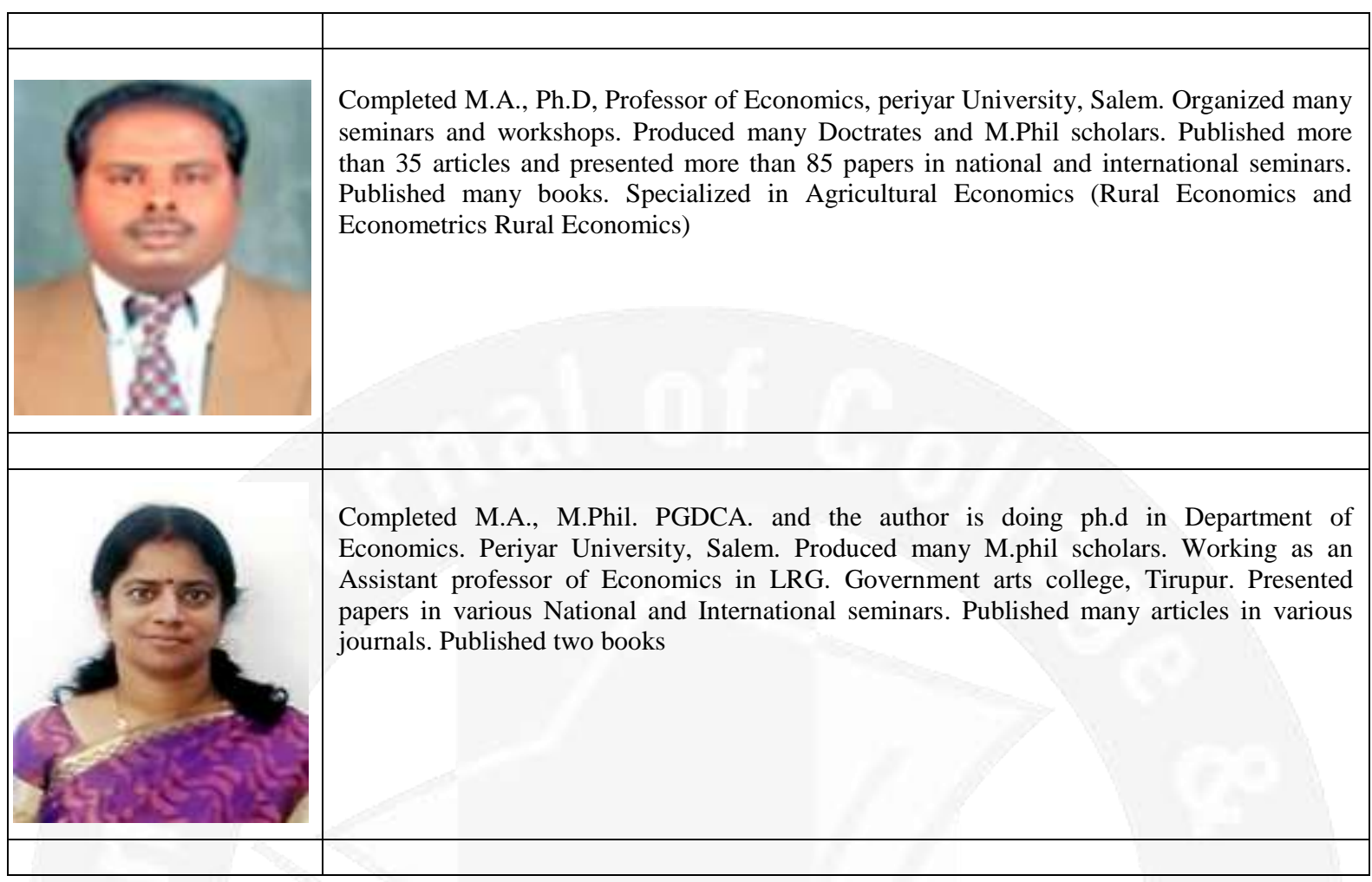

